\title{
Corporate Criminal Liability On Criminal Actions in Consumer Protection
}

\author{
Fifid Bramita \\ Master of Law of Universitas Diponegoro \\ Jl. Imam Bardjo No. 1, Pleburan, Semarang Selatan, Jawa Tengah 50241. \\ fifidbramita18@gmail.com
}

\begin{abstract}
The advancement of information technology affects the crime related to consumer protection. This impact is no longer confined to certain regions or country, but it is tranversing jurisdictional boundaries (transnational). Thus, the variety modes of the crime increase, not only used by individual, but also carried out by corporations. Criminalizing corporation is difficult, especially when related to consumer protection. That is because there are no legal provisions about corporate's position and its responsibility in Criminal Law in Indonesia. Consequently, this condition leads to multi interpretations and thoughts between law enforcement officers. Therefore, it is necessary to have guidelines in handling crime cases done by companies. This study employs normative juridical research method. This research concludes that after the issuance of Indonesia's Supreme Court Regulation Number 13 of 2016 About Procedures for Handling Criminal cases done by corporations, the law enforcement officers are no longer confused on how to handle the crime.
\end{abstract}

Keywords: Corporate Liability; Criminal Actions; Consumer Protection

\section{A. INTRODUCTION}

The development and advancement of technology encourages us to enter into the era of economic globalization. It is sometimes misused by certain parties who are not responsible to gain advantage for himself. One of the negative impacts of this technological advancement is the emergence of criminal acts in terms of consumer protection which is part of the crime in the economic field which causes many victims of crime. In connection with the victims of corporate crime, Muladi as cited by Arief Amrullah, distinguishes between the victims of conventional crime with the victims of corporate crime, "The victims of conventional crime are easily identified, while corporate crime leads to some abstract victims such as government, other companies, or numerous consumers" (Amrullah, 2006).

Information technology advancement that has given an impact on the crime of consumer protection is no longer confined to a particular region of the country, but across the jurisdictional boundaries (transnational) and uses an increasingly varied mode, even committed by a corporation. The corporation has contributed a lot to the development of a country especially in the economic field. But corporations also often give negative effects from activities such as environmental pollution, tax manipulation, labor exploitation, fraud, money laundering and criminal acts in terms 
of consumer protection. Therefore, the impact which has made the law as the regulator and guardian of the community must give attention and regulation to the corporate activities (Nasution, 2015).

As technology advances and the times, a corporation could be positioned as the subject of criminal law and having criminal liability in positive law (Nurmalawaty, 2006). Recognition of corporations as legal subjects who can commit crimes and can be held criminally responsible has been going on since 1635 . This corporate recognition began when the British legal system acknowledged that corporations can be criminally responsible but only limited to minor crimes (Weissmann \& Newman, 2007). Unlike the British legal system, in the United States, the existence of corporations as the subject of criminal law which is claimed to be able to commit a criminal offense and can be held criminally responsible has just recognized in 1909 through court decisions (Orland, 2006).

In further developments, the corporation accountability or the recognition to corporations as subjects of criminal law, which are considered capable of committing crimes and are held responsible for criminal actions, also developed in several countries such as the Netherlands, Italy, France, Canada, Australia, Switzerland and several European countries including in Indonesia.

When the Indonesian criminal law system recognizes corporations as the subject of criminal law, especially those contained in the Consumer Protection Act, it has a major impact on the three basic concepts of criminal law, namely criminal acts, criminal and criminal liability and punishment. Of course the theoretical framework is different between corporations who violate the law and someone who violates the law. Likewise, the determination of criminal liability, the format of errors, the ability of corporate liability in Law Number 8 of 1999 concerning Consumer Protection will be different because the nature and characteristics inherent in the corporation are basically different from the traits and characteristics that exist in humans.

Therefore, it is necessary to examine more deeply the criminal liability in terms of consumer protection stipulated in Law Number 8 of 1999 concerning consumer protection. Based on the description of the background above, there are two main problems to be discussed in this paper both are: (1) How is the Corporate Accountability in the Law Number 8 of 1999 concerning consumer protection connected with the Supreme Court Regulation Number 13 of 2016 regarding the Procedures for managing Criminal Cases by Corporations and (2) What is the sanction system viewed from both the Consumer Protection Act and the Supreme Court Regulation Number 13 of 2016 concerning Procedures for Handling Criminal Cases by Corporations.

\section{B. RESEARCH METHOD}

The method used in this study is normative legal research method with normative juridical approach. Normative legal research is a literature research. Literature research is needed to collect required legal materials such as primary 
legal materials covering the Criminal Code (KUHP), Law Number 8 of 1999 concerning Consumer Protection, Supreme Court Regulation Number 13 of 2016 on how to deal with criminal cases by corporations. Alongside the primary, there are secondary legal materials such as books, legal scientific works, and other written materials used to provide an explanation of some of the terms used in this writing.

\section{DISCUSSION AND ANALYSIS}

1. Corporate criminal liability in Law Number 8 of 1999 On Consumer Protection juncto Supreme Court Regulation Number 13 of 2016 regarding the Procedures for Handling Criminal Cases by Corporations

Corporation is a term commonly used by criminal law experts and criminologists to refer to legal person or body person or in Dutch language called Recht Person (Setiyono, 2005). Satjipto Rahardjo said that the corporation is a legal entity. It consists of corpus, which is its physical structure and into it, the law includes animus elements that make the body have a personality, so that the legal entity is a law creation, then except for its creation, its death is also determined by law (Rahardjo, 1986).

Utrecht stated that the legal entity (Rechts Persoon) is a body that according to the law has the power (authority) to be a supporter of rights, then it is explained that the legal entity of every rights supporter is soulless, or more precisely not human. He also said that corporations are people alliance which the alliance itself, personifically, is subject of the law. It has the self rights and obligations as an entity out of the rights and obligations of its individual member (Krismen, 2014).

Criminal liability is basically individual and bound to the principle of "error" or the principle of culpability or the principle of Geen Straft Zonder Schuld or Keine Strafe Ohne Schuld or no punishment without fault in the case of punishment. The designer of Wetboek van Strafrecht (WvS) is influenced by the principle of the Universitas Delinquere Non Potest or the Societas Delinquere Non Potest, which means that legal entities cannot commit criminal acts (Jaya, 2018). It can be seen from the article 59 of the Criminal Code that stated:

"In terms of the criminally offense done by director, his/her subordinate, the member of management board or the commissaries, then the director, the member of management board or the commissaries who actually involving no crime are not penally punished"

It means that the drafters of the Criminal Code (WvS) agreed that legal entities cannot commit criminal acts and those who can commit criminal acts are only pure humans (Natuurlijke Persoon), while legal people (Rechts Person) cannot commit criminal acts. However, in its development, criminal liability which was originally only oriented to the mechanism of imposing criminal responsibility on humans has shifted along with the progress of human civilization. It happens because of certain phenomena in the law enforcement process, namely in the form of inaccessibility of legal subjects other than humans to be subjected to the criminal liability, even 
though in fact the legal subject has a stake in the occurrence of the intended crime. For example, in terms of the development of science and technology, it has made progress in economic sector so that business actors appear not only individual but also in the form of cooperation in the form of associations of people or assets in the form of corporations. This corporation in conducting activities is of course profit oriented. Therefore, it is possible to carry out actions that can harm other people in achieving their goals.

A. L. Van Strien, put forward three basic theories in determining legal entities (corporations) as subjects of criminal law (Jaya, 2018):

a. Teachings that have a tendency to be "psychological" from J. Remmelink, who argues that criminal law views humans as rational and moral beings (Redelijk Zedelijkewezen)

b. The "sociological" tendency of J. Ter Heide, in which the main concern is not the man but the action (in this connection Ter Heide calls it criminal law released from humans [ontmenseljik strafrecht]).

c. Insights from A.C. 't Hart, where the notion of "legal subject" is seen as a 'Contrafaktisch' juridical understanding.

Rammelink's teaching states that criminal law is not merely a matter of error and punishment (schulden boete) in which the sentence imposed is based on the act of blaming ethically which must be charged to the suspect. Furthermore, in criminal prosecution, the role of human will also play an important role (in this case, human beings place their will voluntarily against the will of the state) (Jaya, 2018).

Ter Heide's teaching states that there is a tendency that criminal law is increasingly released from the human context. According to Ter Heide, the subject matter of criminal law is action. According to him, the detachment from the human context is related to the fact that people are getting increasingly inclined to the functional approach of criminal law where the center of its attention is the social and normative meaning of an action. Because criminal law has been separated from the human context, Ter Heide then concluded the view that only humans can be treated as legal subjects in principle as accomplices (Jaya, 2018).

A.C. 't Hart stated that juridical concepts should not be understood solely as an empirical reality or as ideal ideas which a priori set a norm that is above sociological historical reality. Because this juridical concept occupies an intermediary position, it cannot be seen as the second part of that understanding but tends to be the opposite of both. Not only in an isolated position, but also interrelated according to theirstructure of understanding and logic. In this way, the juridical concept gives individuals the space to defend themselves or oppose not only other individuals who are in the insight of life/reality itself (Jaya, 2018).

The recognition of corporate criminal liability to be criminalized, through several stages: 
a. First stage

At this stage, restrictions are imposed so that the nature of the offenses committed by corporations is limited to individuals (persons). If a criminal act occurs in a corporate environment, then the criminal act is deemed to be carried out by the corporate executor or charged to the corporate administrator "the task of taking care" (zorgplicht).

b. Second stage

The special formulation of the law which states that a criminal offense can be carried out by a union or business entity (corporation) and that responsibility is also a burden on the board of legal entities. If a legal entity commits a crime, the criminal charges and criminal penalties must be borne by the management. Finally, criminal responsibility has shifted from member to management to those who ordered it, or with a prohibition to do it if it neglected to lead the legal entity seriously. In this stage the corporation can be a maker of offenses, which will be accounted for by the members of the board, and must be stated explicitly in the law. In this second stage, criminal responsibility directly from the corporation has not yet emerged (Muladi \& Priyatno, 2012).

c. Third Stage

This third stage is the beginning of the responsibility directly imposed on the corporation that began after World War II. At this stage it is possible to sue corporations and hold corporations accountable under criminal law. The reason for regulating corporations as makers and those who must be held accountable for their actions is because in economic and fiscal delicts, the profits obtained by the corporation or the losses suffered by the community can be so large that it will not be balanced if the punishment is only imposed on the corporate management. The reason is that by punishing the administrators, there is absolutely no or no guarantee that the corporation will not repeat the crime. Corporate punishment with this type and weight in accordance with the nature of the corporation is expected to force the corporation to comply with the relevant regulations (Priyatno, 2004).

According to Remy Sjahdeini, there are two main teachings that justify the imposition of criminal responsibility on corporations. These teachings are the doctrine of strict liability and the doctrine of vicarious liability. The doctrine of Strict liability is defined as a criminal act by not requiring an error of the perpetrator of one or more actus reus (Heaton, 2006). The strict liability is liability without fault. With the same substance, the concept of strict liability is formulated as The Nature of the strict liability offence, which is the one that crimes which does not require any manners with regard to at least one element of their "actus reus" (the concept of absolute liability is a form of violation/the crime in which does not require an element of error, but only implies an act) (Arief, 2002). Strict liability is absolute responsibility without seeing the inner attitude or mens rea of the perpetrator. This 
model of accountability is the most practical responsibility (Anjari, 2016). Meanwhile, the Doctrine of Vicarious liability is commonly referred to as substitute accountability, according to Barda Nawawi Arief, vicarious liability is a concept of someone's responsibility for mistakes made by other people, such as the actions carried out within the scope of their work field (the legal responsibility of one person for the guilt of another, as for example, when the acts are done within the scope of employment) (Arief, 2002).

The adaptation of the corporate criminal responsibility in consumer protection law in Indonesia is characterized by the mentioning of the term of "business actors" as the subjects of criminal acts of consumer protection in Law Number 8 of 1999 concerning Consumer Protection as the sound of Article 1 point 3 reads:

"Perpetrator is either individual person or corporate in the form of legal entity or non-legal entity which established and domiciled in Indonesia or doing its activities in Indonesia's jurisdiction either in its own or in cooperation through the agreement to administer business activities in various economic sectors."

Furthermore, in article 61, it is explained that criminal prosecution can be carried out against business actors and/or their administrators. They are the company, corporation, State-Owned Enterprises, small union, importer, trader and distributor.

The stage of Prosecution and criminal justice against corporate business actors (companies, State-Owned Enterprises) has a problem in law enforcement practices because Law Number 8 of 1999 on Consumer Protection still requires an element of "error" in the formulation of its norms. In fact, according to the doctrine of strict liability, from a common law point of view, an action can be punished on the basis of harmful conduct, without questioning whether there is intentionality (opzet) or "negligence" (culpa; negligence) (Imansyah, 2016).

The Error element is contained in article 22, which states that "the weight of proving of the existence or non-existence of negligence in criminal act as it meant in Article 19 Paragraph (4), Article 20 and Article 21 is on defendant". According to the explanation of article 22 of the consumer protection law, the proof system uses a reverse proof verification system, where the weight of the proof is on the defendant but does not rule out the possibility for the prosecutor to carry out the verification. In this case, the business actor who proves the presence or absence of an element of error in matters as specified in article 19 paragraph (4), which is the provision of compensation does not eliminate the possibility of criminal charges based on further evidence of an element of error.

In 2016, the Supreme Court issued a Supreme Court Regulation (PERMA) Number: 13 of 2016 concerning Procedures for Handling Criminal Actions by Corporations. This PERMA was issued to answer the polemic and legal debate that 
occurred among law enforcement officials regarding the issue of corporal punishment and as a special procedural law that applies to the handling of criminal acts by corporations.

Before PERMA No. 13 of 2016 was issued, the law enforcement officers such as the police, prosecutors, the corruption eradication commissions (i.e. Komisi Pemberantasan Korupsi [KPK]) even judges had difficulties in formulating and penalize corporations because the law enforcement officials still adhered to the Book of Criminal Procedural Law (i.e. Kitab Undang-Undang Hukum Acara Pidana [KUHAP]), where the focus of punishment was only given to perpetrators/its administrators (individuals), even though in fact many corporations are used to simplify and run a criminal act syndicate, for example a corporation is established as a place to conduct money laundering, or other activities aimed at disguising actions and proceeds of crime.

Due to the absence of legal arrangements regarding the position and accountability of corporations in criminal law and procedural law, the emergence of different interpretations and thoughts between law enforcement officers, resulted in the rarity of including corporations as perpetrators of crimes in the investigation and prosecution. Even there are many prosecutors did not include corporations as perpetrators of crimes in their indictments under the pretext that corporate administrators had been convicted, had paid fines, and substituted money, so the corporation was left free because the case is considered complete.

After PERMA No. 13 of 2016 in accordance with Article 4 paragraph 2 of Supreme Court regulation number 13 of 2016, in imposing criminal acts on Corporations, judges can assess corporate errors with the following parameters:

a. The corporation can get the benefit or advantages from the crime or the crime is carried out for the benefit of the Corporation;

b. The corporation allows for criminal acts; or

c. The corporation does not take any required protocol to take precautions, prevent greater impacts and ensure compliance with applicable legal provisions to avoid the occurrence of criminal acts.

2. Sanctions System in the Consumer Protection Act and in the Supreme Court Regulation Number 13 of 2016 concerning Procedures for Handling Criminal Cases by Corporations

Corporate criminal liability that harms the consumers in order to provide legal protection for consumers uses 3 sanctions systems (Jaya, 2018):

a. Civil Law Sanctions System

The application of civil law sanctions, in accordance with Article 45 of the Consumer Protection Act, is carried out through an institution aiming at resolving the disputes between consumers and business actors or through courts in the general court. Consumer dispute resolution can be reached through the court or outside the court based on the voluntary 
choice of the parties of dispute. In its sense, the consumer or business party can voluntarily choose whether through the court or outside the court regarding the procedure that will be used in resolving the dispute. If an attempt to resolve the dispute outside the court has been chosen, the lawsuit through the court can only be carried out if the dispute resolution effort outside the court is unsuccessful, which must be declared by one of the parties or by all the parties of the dispute. According to article 45 paragraph (3) concerning consumer protection laws, the settlement of disputes outside the court does not relieve/eliminate criminal responsibility from the business actors. Dispute resolution outside the court according to article 47, is held to reach an agreement on the form and amount of compensation and/or regarding certain actions to ensure that the losses suffered by the consumer will not occur again or will not recur.

b. Administrative Legal Sanctions System

The application of administrative legal sanctions in the form of administrative sanctions in the form of compensation of money stipulated in article 60 of the Consumer Protection Act which reads:

(1) The consumer dispute resolution body is authorized to impose administrative sanctions on business actors who violate Article 19 paragraph 2 and paragraph 3, Article 20, Article 25, and Article 26.

(2) Administrative sanctions in the form of maximum money compensation of Rp. 200,000,000.00 (two hundred million rupiahs).

(3) The procedure for stipulating administrative sanctions as referred to paragraph 1 shall be further stipulated in statutory regulations.

c. Criminal Law Sanction System

Criminal sanctions against business actors who violate the provisions in the form of prohibitions in consumer protection laws are regulated in Article 61, Article 62 and Article 63.

In the article 61 of the Consumer Protection Law, it is explicitly stated that prosecution can be carried out on "business actors" and/or "administrators". The definition of a business actor is stated in Article 1 number 3 of the Consumer Protection Act, which confirms that business actors also include business entities, both in the form of legal entities or non-legal entities.

The article 62 paragraph (1) and paragraph (2) of the Consumer Protection Law only determines criminal threats against restrictions carried out by business actors spread in several articles of the Consumer Protection Act, while in article 62 paragraph (3) is a bridge for the enforcement of provisions of other crimes when the violation committed by the business actor results in serious injury, serious illness, permanent disability or death. Article 62 itself reads as follows:

(1) Business Actors who violate the provisions referred to in Article 8, Article 9, Article 10, Article 13 paragraph 2, Article 15, Article 1 
paragraph 1 letter a, letter b, letter c, letter c, paragraph 2, and Article 18 shall be sentenced to imprisonment for a maximum of 5 (five) years or a fine of a maximum of Rp. 2,000,000,000.00 (two billion rupiah).

(2) Business actors who violate the provisions as referred to in Article 11, Article 12, Article 13 paragraph 1, Article 14, Article 16, and Article 17 paragraph 1 letter $\mathrm{d}$ and letter f shall be sentenced to imprisonment of a maximum of 2 (two) years or penalty of a maximum of Rp. 500,000,000.00 (five hundred million rupiah).

(3) For violations resulting in serious injury, serious illness, permanent disability or death, the applicable criminal provisions apply.

The legislative policy regarding criminal sanctions contained in Article 62 of the Consumer Protection Act only regulates the types of imprisonment and alternative penalties as adopted by the Criminal Code. Although the beginning of the sentence in this provision uses the word or term "business actor", not "whoever", but this provision appears to be more directed at the subject of natural human law (natuurlijk persoon) as adopted by the Criminal Code. This also appears when observing the provisions of Article 62 paragraph (3) that for violations resulting in serious injuries, serious illness, permanent disability or death, the applicable criminal provisions apply. The definition of article 62 paragraph (3) of the Consumer Protection Act basically states that not all criminal acts that can be carried out by legal subjects of individuals (persoonlijk), can also be done by corporations, because it is difficult to apply the problem of criminal liability. Like for example in criminal acts of rape, molestation, etc.

Article 63 states that there are additional penalties which could be imposed in criminal sanctions as it mentioned in Article 62. Those additional penalties are as follows:

a. seizure of certain goods;

b. announcement of the judge's decision;

c. compensation payment;

d. order to terminate certain activities that cause consumer losses;

e. obligation to withdraw goods from circulation; or

f. revocation of business license

The provisions of Article 63 of the Consumer Protection Law do not explicitly regulate the types of sanctions that can be imposed on corporations. This provision regulates additional crimes that are facultative in nature, not a necessity, that is, if the judge views the need for additional crimes. If the judge views that it is not necessary, then the criminal fine is the only type of sanction that can be imposed on the corporate business actor. 
M. Sholehuddin stated that the existence of new crimes and the incapability of sanctions to overcome corporate crime are demanding the reorientation and reformulation of sanctioning based on double track system (Sholehuddin, 2003). The discussion of the types of sanctions in the consumer protection law is less strict in adhering to the concept of "Double Track System". It can be seen in the formulation of the offense which only lists one type of sanction in criminal law, namely criminal sanctions. whereas sanctions for action are only additional sanctions. In other words, the consumer protection law has not been consistent in adhering to the Double Track System concept.

In general, the double track system is a two-lane system regarding the imposition of sanctions in criminal law, namely the type of criminal sanction on the one hand and the type of sanction for action on the other. The double track system requires two types of sanctions in an equal position in the criminal law sanction system. From the point of view of the basic idea of the double track system, the equality in the position of criminal sanctions and sanctions for actions is very useful to maximize the use of both sanctions in a precise and proportional manner.

The application of the double track system principle can be seen in Law Number 7 Drt. 1955 concerning Investigation, Prosecution and Economic Criminal Justice as follows:

Article 8.

Rules of conduct are:

a. placement of a convicted company, where an economic crime is carried out under forgiveness for a period of three years at the most, in the case of economic crimes that are a crime and in the case of economic crimes it is a violation for a period of two years;

b. requires payment of as many as one hundred thousand rupiahs and for a maximum period of three years in the case of economic acts of crime; in the event that economic crimes are a violation, the guarantees shall be in the maximum of fifty thousand rupiahs for the perpetual time by the convicted person;

c. obliging to pay a sum of money as revocation of profits according to estimates obtained from a criminal act or such criminal offenses, in the event that sufficient evidence that the crime is carried out by law;

d. Obliging to do what is neglected without rights, exclude what is done without rights, and do services to correct the consequences of each other, all at the expense of the condemned, just the judge does not determine otherwise.

Article 9

a. The disciplinary actions referred to in article 8 are imposed together with criminal penalties, except in the case of article 44 of the Criminal Code, 
with the understanding that such acts cannot be imposed in article 8 sub b.

b. In the event that Article 44 of the Criminal Code is applied, the time specified for placement under forgiveness can be extended every time of the year with the judge's decision.

The sentence which states "dropped together with criminal penalties" clearly shows the existence of a double track system principle in regulating sanctions against perpetrators of economic crimes. The application of the double track system principle to the corporation is something that needs to be considered because the parties behind the corporation are very complex. The imposition of sanctions on corporations not only affects the corporation concerned, but also on workers or employees or people whose lives depend on the corporation concerned.

After the issuance of Supreme Court Regulation Number 13 of 2016 concerning Procedures for Handling Criminal Cases by Corporations, Sanctions or laws that can be imposed on Corporations according to the guidelines outlined in Article 25 paragraph (1) Perma Number 13 Year 2016 concerning Supreme Court Regulation Number 13 Year 2016 concerning Procedures for Handling Criminal Cases by Corporations, are:

a. Judges impose criminal penalties against Corporations in the form of additional principal and/or criminal penalties.

b. The principal penalty that can be imposed on the Corporation as referred to in paragraph (1) is a fine.

c. Additional penalties are imposed on the Corporation in accordance with the provisions of the legislation.

The principal crimes that can be imposed on Corporations are criminal penalties while additional criminal sanctions imposed on Corporations are as stipulated in other laws and regulations, namely Article 10 of the Criminal Code and other types of criminal provisions that are spread in other laws as lexspecialis of the Criminal Code which is legigenerali. In the case of additional Crimes, in PERMA Number 13 of 2016 concerning Supreme Court Regulation Number 13 of 2016 concerning Procedures for Handling Criminal Cases by Corporations their implementation is regulated in Article 30 to Article 33 whose contents are as follows:

Article 30:

"Additional crimes or disciplinary actions or other actions against the Corporation are carried out based on the Court's decision."

Article 31:

a. In the event that the Corporation is imposed with an additional sentence in the form of seizure of evidence, then the seizure of evidence is carried 
out no later than 1 (one) month after the decision has permanent legal force.

b. In case there are strong reasons, the period as referred to in paragraph (2) can be extended for a maximum of 1 (one) month.

c. In the event that there are profits in the form of assets arising from the proceeds of crime, then all profits will be confiscated for the state.

Article 32:

a. Corporations subject to additional penalties in the form of substitute money, compensation and restitution, the procedures for their implementation are carried out in accordance with the provisions of the legislation.

b. In the case of additional penalties in the form of substitute money, compensation and restitution imposed on the Corporation, the Corporation shall be granted a maximum period of 1 (one) month after the decision has the legal force to pay substitute money, compensation and restitution.

c. In the event that there are strong reasons, the period as referred to in paragraph (2) may be extended for a maximum of 1 (one) month.

d. If the Corporation convict does not pay substitute money, compensation and restitution as referred to in paragraph (2) and paragraph (3), the property can be confiscated by the prosecutor and auctioned to pay for replacement money, compensation and restitution.

Article 33

"Corporations subject to additional criminal penalties in the form of repairs due to criminal acts, procedures for their implementation are carried out in accordance with statutory provisions."

\section{CONCLUSION}

Corporate liability is not regulated in the Indonesian Criminal Code because the parties who can be considered as the subjects of criminal law are only individuals in natural biological connotations (naturlijkee person). However, in its development, corporations are seen as subjects in criminal law. This can be found in criminal law legislation outside the Criminal Code which has determined the corporation as the subject of criminal law that can be sued for criminal responsibility, as found in Law Number 8 of 1999 concerning Consumer Protection. Corporate criminal liability can be requested from corporations even though in criminal acts the corporation has no element of error. This refers to the doctrine of strict liability. Corporations are accountable for actions committed by the corporation's management, in this case the corporation as a substitute responsibility for actions taken by the corporate management. This refers to the doctrine of vicarious liability. 
Before PERMA No: 13 of 2016 concerning the Procedures for the Management of Criminal Actions by Corporations was issued, law enforcement officers found it difficult to formulate and penalize corporations, including prosecuting the perpetrators of criminal acts of consumer protection regulated in Law Number 8 of 1999 concerning Consumer Protection. That is because the absence of legal arrangements regarding the position and accountability of corporations in criminal law and 'procedural law', resulted in the emergence of multiple interpretations and contradictory thoughts between law enforcement officers. This has resulted in the investigation and prosecution processes rarely include corporations as perpetrators of criminal acts. In addition, the difficulties faced by law enforcement officials in dealing with criminal acts committed by corporations are more than a lack of a good and correct understanding of principles, concepts and theories in criminal law. After the issuance of PERMA Number 13 of 2016 law enforcement officers can formulate and penalize corporations without any interpretation because there are already implementing guidelines.

There are 3 sanctions systems in the Consumer Protection Law that accommodate every legal field, namely civil law with civil sanctions (compensation), administrative legal sanctions system with administrative sanctions and criminal law sanction systems with types of criminal sanctions and sanctions for action (additional sanctions) discussion of the types of sanctions in the consumer protection law is less strict in adhering to the "Doeble Track System" concept. This can be seen in the formulation of the offense which only includes one type of sanction in criminal law, namely criminal sanctions. whereas sanctions for action are only additional sanctions. In other words, consumer protection laws have not consistently adhered to the Doeble Track System concept. After the issuance of Supreme Court Regulation No. 13 of 2016 concerning Procedures for Handling Criminal Cases by Corporations, the sanctions are in the form of Basic Crimes and Additional Criminal Cases. The principal criminal offense is a criminal fine while an additional criminal is in accordance with other laws and regulations, namely Article 10 of the Criminal Code and other types of criminal provisions that are spread in law.

\section{REFERENCES}

Amrullah, A. (2006). Kejahatan Korporasi (The Hunt for Mega Profits and The Attack on Democracy). Malang: Banyumedia Publishing.

Anjari, W. (2016). Pertanggungjawaban Korporasi Sebagai Pelaku Tindak Pidana. Jurnal Ilmiah Widya Yustisia, 1(November), 116-121.

Arief, B. N. (2002). Perbandingan Hukum Pidana. Jakarta: Rajawali Press.

Heaton, R. (2006). Criminal Law Text Book. London: Oxford University Press.

Imansyah, I. (2016). Pertanggungjawaban Korporasi dalamTindak Pidana Perlindungan Konsumen. Jurnal IUS Kajian Hukum Dan Keadilan, 4(2), 154164.

Jaya, N. S. P. (2018). Hukum dan Hukum Pidana di Bidang Ekonomi. Semarang: Badan 
Peneribit Universitas Diponegoro.

Krismen, Y. (2014). Pertanggungjawaban Korporasi dalam Kejahatan Ekonomi. Jurnal Ilmu Hukum, 4(1), 133-160.

Muladi, \& Priyatno, D. (2012). Pertanggungjawaban Pidana Korporasi. Jakarta: Kencana Prenada Media Group.

Nasution, E. S. (2015). Pertanggungjawaban Pidana Korporasi dalam Tindak Pidana Pencucian Uang. Jurnal Mercatoria, 8(2), 132-144.

Nurmalawaty. (2006). Faktor Penyebab terjadinya Tindak Pidana Pencucian Uang (Money Laundering) dan Upaya Pencegahannya. Jurnal Equality, 11(1), 12-18.

Orland, L. (2006). The Transformation of Corporate Criminal Law. Brooklyn Journal of Corporate, Financial \& Commercial Law, 1(1).

Priyatno, D. (2004). Kebijakan Legislasi tentang Sistem Pertanggungjawaban Pidana Korporasi di Indonesia. Bandung: CV. Utomo.

Rahardjo, S. (1986). Ilmu Hukum. Bandung: Alumni.

Setiyono, H. (2005). Kejahatan Korporasi Analisis Viktimologi dan Pertanggungjawaban Korporasi dalam Hukum Pidana Indonesia. Malang: Bayu Media Publishing.

Sholehuddin, M. (2003). Sistem Sanksi dalam Hukum Pidana, Ide Dasar Double Track System \& Implementasinya. Jakarta: Raja Grafindo Persada.

Weissmann, A., \& Newman, D. (2007). Rethinking Criminal Corporate Liability. Indiana Law Journal, 82(2), 411. 